\title{
EFFECT OF POWER QUALITY ON HUMAN HEALTH AND SAFETY
}

\author{
Richard VELIČKA ${ }^{1}$, Eva VELIČKOVÁ
}

Review article

\begin{tabular}{ll}
\hline Abstract: & Every product which is supply on the market has to fulfil definite parameters. These \\
& parameters ensure usability of product in consumption and guarantee safety of product in \\
& relation to health protection and protection of property. The same requirements concern \\
& supplied elektricity in distribution network. Most devices are dependent on the source \\
& of electrical energy today. For this reason, it is very important to follow parameters of \\
electrical energy for the error - free operation of these devices to prevent health damage \\
(e.g. flashing of light sources owing to flickering effect - factors of flickering) or fires \\
(e.g. fires caused by insulation failure owing to inadmissible overvoltage in supply \\
network). The parameters of power quality are defined in the standard ČSN EN 50160 \\
ed. 3 . Methods of measurement are mentioned in the standard ČSN EN 61000 - 4 - 30. \\
Safety, the parameters of power quality, flicker, Total Harmonic Distortion (THD).
\end{tabular}

\section{Introduction}

At present, most appliances are powered by electricity from the public distribution network. Besides, these devices are mostly operated by regular users without any electrical engineering qualifications. These users approach the appliances simply from a user's point of view, and it is the responsibility of the electrical power supplier to ensure its quality necessary for failure-free operation of the powered equipment. The electricity obviously cannot be expected to have the same qualitative parameters within the whole power supply network, therefore the producers of appliances must take into account a certain range of quality parameters. What answer do we get if we ask regular users a completely trivial question: What voltage is there in a socket? The answer is mostly: $230 \mathrm{~V}$. However, nobody wonders whether it is true, or if it is not also important what is the waveform of this voltage. Many users are not even aware of the fact that it is alternating voltage. The above mentioned examples show that wide public have no idea that with respect to size, there is a certain defined voltage range, that it has a certain frequency, that its waveform can be defined, etc. These changes are also caused by adding more appliances to the network, while others are removed from it all the time. This continuous process results in continuous changes of qualitative parameters in the power supply network.

\section{Materials and methods}

\section{Power Quality}

Electric power qualitative parameters are defined by ČSN (Czech National Standard) EN 50160: Characteristics of electric power voltage supplied from public distribution networks (ČSN EN 50160 ed. 3, 2011, 32 p., EN 50160, 2010), which has been going through turbulent changes in the past years, based on the discussions in technical standardization committees at the European level. At present, the version of the series from 3 February 2011 has been approved. This standard describes 13 parameters of electric power quality that the supplier has to ensure. Limits of the parameters are defined here both for low voltage networks (e.g. $230 \mathrm{~V}$ ) and for high voltage networks (e.g. $22 \mathrm{kV}$ ). These parameters include:

1) the electric network frequency,

2) the supply voltage value,

3) the voltage deviations,

4) rapid changes in voltage:

- intensity of rapid changes of voltage,

- the extent of flicker perception (blinking factors),

5) short-time supply voltage drops,

6) supply voltage asymmetry,

VŠB - Technical University of Ostrava, Faculty of Electrical Engineering and Computer Science, Ostrava, Czech Republic, richard.velicka@vsb.cz

2 VŠB - Technical University of Ostrava, Faculty of Safety Engineering, Ostrava, Czech Republic, eva.velickova@vsb.cz 
7) harmonic voltage,

8) interharmonic voltage,

9) levels of signal voltage in power voltage,

10) short-term power supply cut-offs,

11) long-term power supply cut-offs,

12)temporary overvoltage at the network frequency between live conductors and the ground,

13) temporary overvoltage between live conductors and the ground.

In ČNN EN 50160, the guaranteed values are defined for the first 9 parameters, the measurement intervals, observation periods and boundary probability performance of the defined limits. Only informative values are stated for the last four parameters.

In ČSN EN 50160, the percentage of the quality deviations is stated for important quality parameters including the percentage of time, where this has to be fulfilled. For example this is the case of supply voltage, which, in usual operation conditions, must be $\pm 10 \% U_{n}$ in $95 \%$ of time in the measured interval of 1008 samples (10-minute records over the period of 7 days) and $+10 \%$ to $-15 \% U_{n}$ in $100 \%$ of time. Most appliances are designed for this range of power supply $\left( \pm 10 \% U_{n}, U_{n}=230 \mathrm{~V}\right)$.

Other parameters are defined in a similar way, but since the above mentioned standard is relatively extensive (there are several tens of pages), it is not possible to state everything in detail.

\section{Parameters Having an Impact Mainly on the Appliance}

Most parameters stated in ČSN EN 50160 (ČSN EN 50160 ed. 3, 2011, 32 p., EN 50160, 2010), maybe all of them, have, to a larger or smaller extent, an impact on the appliances they supply. Some appliances may be sensitive to voltage drops, which manifests itself e.g. by a decrease in brightness with light sources and by higher degree of heating with engines. Some appliances, such as consumer electronic products, cannot withstand short-term or long-term overvoltage. If supply voltage is close to the upper limit, it means considerable decrease of service life for light bulb sources. High content of harmonics (the multiples of the basic frequency of $50 \mathrm{~Hz}$ ) result in more frequent electronic failures, and mainly in irregular operation of engines and engine overheat. We would probably find many other examples why appliances need to be supplied by the defined electric power to work well and reliably. However, it does not always depend on the electric power suppliers. We often cause harm to ourselves by using low quality appliances, which results in regressive impact on the power supply network. At present, there is an enormous rise in fluorescent compact lights and other appliances with switching connections. These connections are very small and energy-saving, however, they have one negative property: they regressively generate the fifth and the seventh harmonic. It results in deformation of the sinusoidal shape of voltage with all the above mentioned consequences and other problems. The monitored parameters also include harmonic content, both individually and in the form of so called factor of total harmonic voltage distortions $T H D_{U}$ (Total Harmonic Distortion). $T H D_{U}$ is calculated as a relation between harmonics and the basic harmonic according to the following formula:

$$
T H D_{U}=\frac{\sqrt{\sum_{i=2}^{50} U_{i h}^{2}}}{U_{1}} \cdot 100 \quad[\%]
$$

where $U_{i h}$ is voltage corresponding to $i$-th harmonic; $U_{1}$ is voltage at the first harmonic (fundamental frequency $50 \mathrm{~Hz}$ ).

Limit for $T H D_{U}$ is $8 \%$ for the distribution network and it must be fulfilled in $95 \%$ of time in weekly measurement with the average ten-minute values recorded.

A good quality appliance is designed not to have a regressive impact on the power supply network and not to be influenced by other appliances. In other words, it meets the requirements of standards for EMC (Electromagnetic compatibility). However, this often does not apply on "cheap" appliances.

\section{Parameters Having an Impact on Health and Safety}

Perhaps no electric power quality parameter causes any injury or damage. It is only a condition with potential above mentioned consequences. At present, one of the most frequently discussed parameters is flicker. Flicker is a quality parameter existing in the supply distribution system as a result of e.g. interrupted load or a large number of switching sources. The appliances causing high flicker, include for example automatic welding machines, gang saws for cutting wood, or induction furnaces. Why is flicker dangerous? Because it causes voltage fluctuation in the power supply network and this fluctuation is dangerous not only for other appliances, but also for people. Some individuals are more sensitive to blinking of light sources or at least to fluctuation of their brightness. This may cause tiredness, headaches and, in some 
cases, epileptic seizure. If something like that happened during a certain dangerous work activity, it might have tragic consequences. (Velička, 2008) With respect to measurement, this parameter is relatively complicated. The algorithm for measuring flicker is described in ČSN EN 61000 - 4 - 15 (ČSN EN 61000 - 4 - 15 ed. 2, 2011, 56 p., IEC 61000 - 4 $-15,2010)$ and includes the block for measurement, the block of human organism impact, and statistics. The result is $P_{S T}$ - short-term flicker (ČSN EN 50160 ed. 3, 2011, 32 p., EN 50160, 2010), for which it is applicable:

$P_{S T} \leq 1$ (in 10-minute intervals in $95 \%$ of time)

Further, the value $P_{L T}$ - a long-term flicker ( $\check{C}$ SN EN 50160 ed. 3, 2011, 32 p., EN 50160, 2010) (in 2 hours from $P_{S T}$ ). It is calculated from the relation:

$$
P_{L T}=\sqrt[3]{\frac{\sum_{i=1}^{n} P_{S T_{i}}^{3}}{12}}[-]
$$

where $i=1,2,3, \ldots n,(n=12$, twelve10-minute records in 2 hours); $t_{\text {long }}=n \cdot t_{\text {short }}$ (time for measuring short-term and long-term flicker); $P_{S T}$ - short-term flicker.

$P_{L T}$ value must be smaller or equal to 1 for the whole time period (100\% of time).

These parameters are based on statistical observations of sensitivity of a significant group of people to the fluctuation of $60 \mathrm{~W}$ bulb luminous flux. It is known that human organism, or more precisely eye - brain is most sensitive to fluctuation of light with frequency of $8.8 \mathrm{~Hz}$. However, this is the statistical mean value, while the impact of fluctuation on a person may be individual. The measurement chain is designed for a bulb, which is not used so much at present, so the methodology is expected to be adjusted in the near future, and it will probably be focused on compact fluorescent sources.

Another quality parameter which may have larger impact on safety is overvoltage. Overvoltage can occur in a few cases. If it is, for example, caused by a storm, it is not the case of a normal operation state of the power supply network, and this parameter is not included in the quality parameters according to ČSN EN 50160. Another possibility of overvoltage occurrence in the power supply network is disconnecting of big appliances or setting transformer taps in such way that voltage parameters are fulfilled at the end of the network, but there is overvoltage at the transformers. This overvoltage causes aging of insulation, damage to electronic ballast for lighting fixtures and other electric and electronic appliances. Even if dielectric strength of new appliances is about $4 \mathrm{kV}$, aging of insulation may result in creation of a conductive path, which might subsequently cause a fire. This is the worst variant, mostly the appliance in "only" destroyed. To prevent a fire, residual current device can be installed in the building for $300 \mathrm{~mA}$ current, together with an alarm system monitoring the temperature within the cable space.

\section{The Way of Measurement of the Power Quality Parameters}

The procedures for measuring individual quality parameters are stated in ČSN EN 61000 - 4 - 30 (ČSN EN 61000 - 4 - 30 ed. 2, 2009, 40 p., IEC 61000 - 4 - 30, 2008). This standard defines the way of measurement of individual quality parameters and the intervals of recording them. In most cases, voltage for the frequency of $50 \mathrm{~Hz}$ is measured as an effective value from the given effective values. These ten-minute periods are evaluated according to ČSN EN 50160 limits. The exception is the long-time flicker PLT, which is recorded in two-hour intervals, as well as drops and overvoltage, which are evaluated as an effective value of voltage in one half cycle. Evaluation of parameters in a half cycle places high demands on technical equipment, therefore the standard ČSN EN 61000 - 4 - 30 ed. 2 defines the classification of measuring instruments. The top class is A, which meets all the conditions for measurement with regard to accuracy as well as to the measurement methods. The instruments belonging to the class $\mathrm{B}$ do not have to meet all the conditions for measurement. The producer may for example define a method of measurement of a certain parameter. However, the results must be correct. The instruments belonging to the last class, the class $\mathrm{S}$, are monitoring devices and the measurement is more accurate than with class B. However, they do not have to meet all the requirements for the class $\mathrm{A}$. The class $\mathrm{S}$ has replaced the class $\mathrm{C}$, stated in the previous edition of the standard.

\section{Results}

The following figure (Fig. 1) shows a typical course of the current drawn by the appliance with a switching source. It is clear from the course that even if the effective value of the current is $1.6 \mathrm{~A}$, the pulse amplitude reaches almost $12 \mathrm{~A}$. In this case, at sinusoidal current consumption, its amplitude would reach only $2.26 \mathrm{~A}$. 


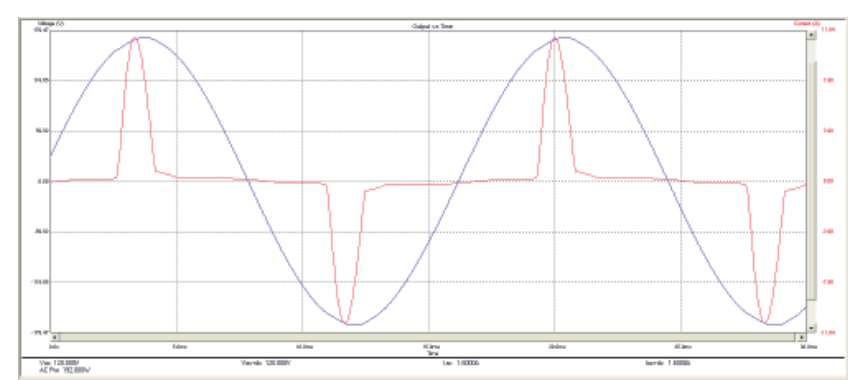

Fig. 1 The course of voltage and current for an appliance with a switching source
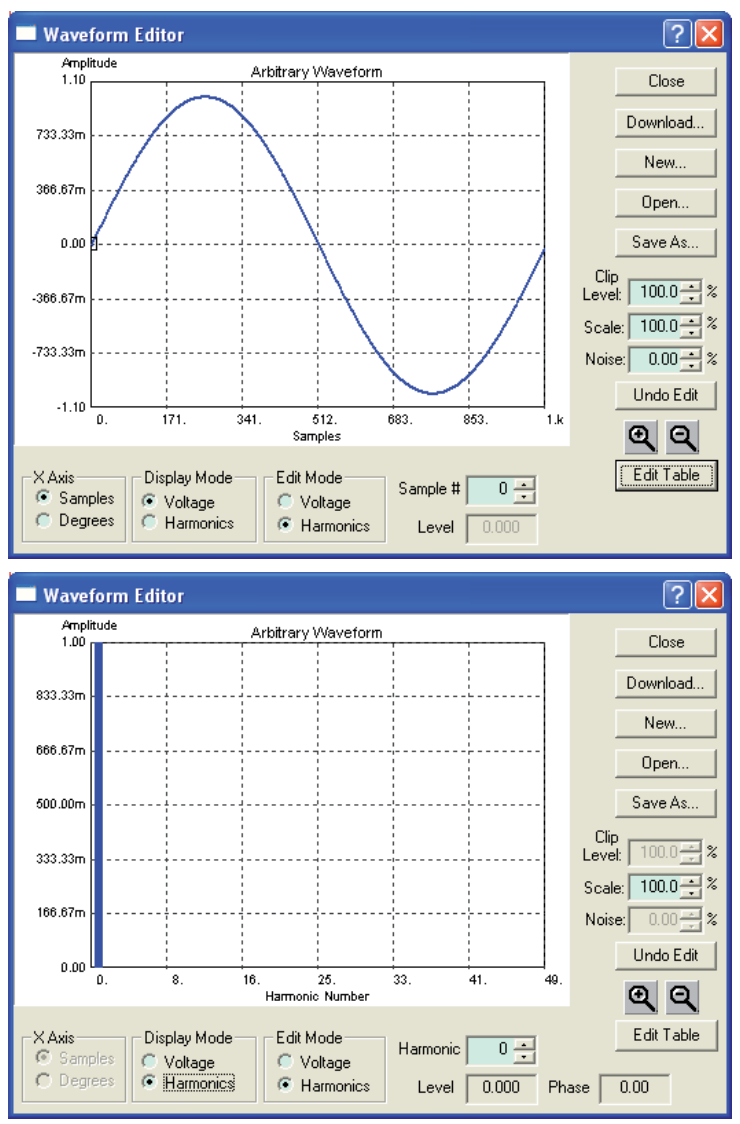

Fig. 2 The course of sinusoidal voltage, harmonics

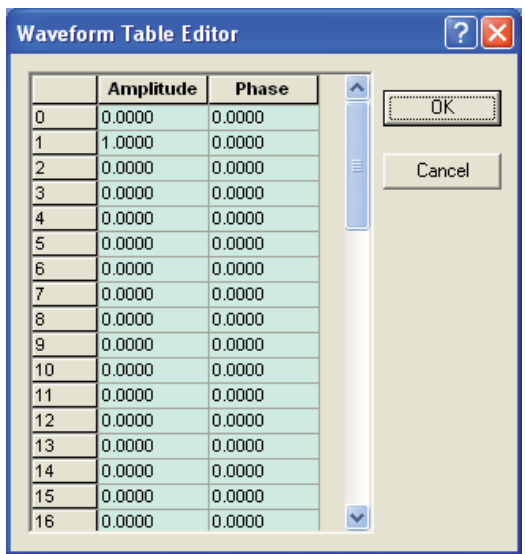

Fig. 3 Table definition
While measuring in the network with the possibility to display its course, a significant deformation at top parts of the expected sinusoidal course can be seen according to Fig. 2 and Fig. 3 .

The course of voltage with this deformation caused mainly by the fifth and seventh harmonic (or, as the case may be, by the ninth and $11^{\text {th }}$ harmonic) is shown in Fig. 4 and 5.
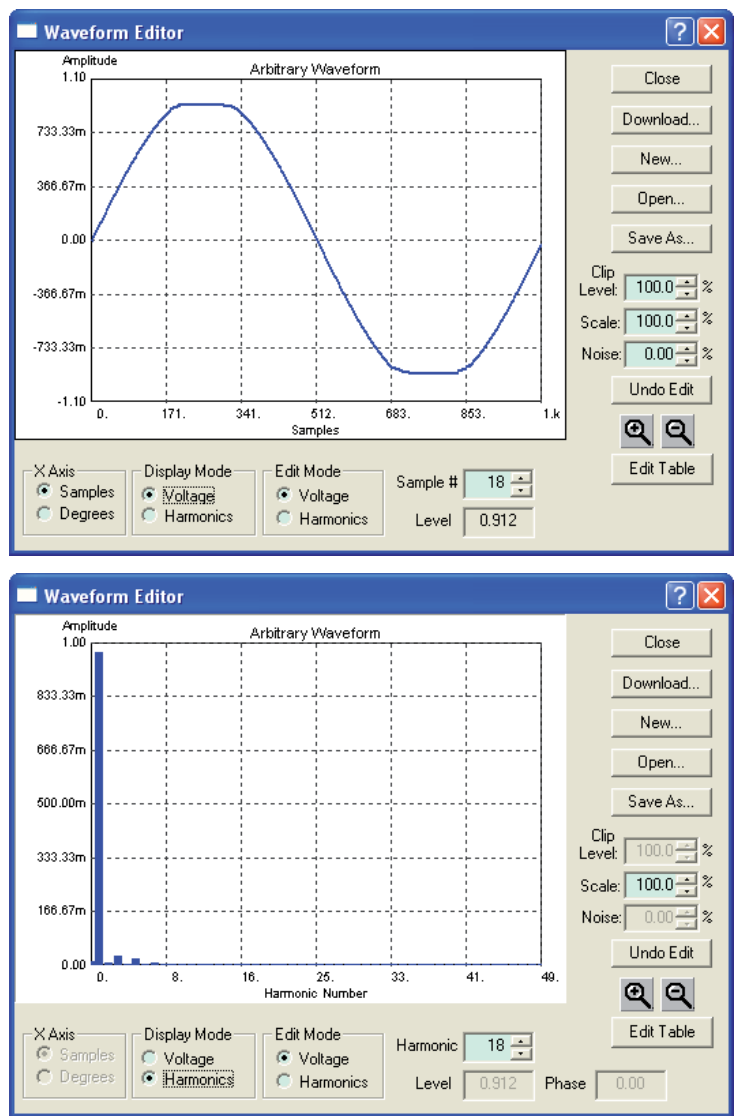

Fig. 4 The usual course of supply voltage in the network, harmonics

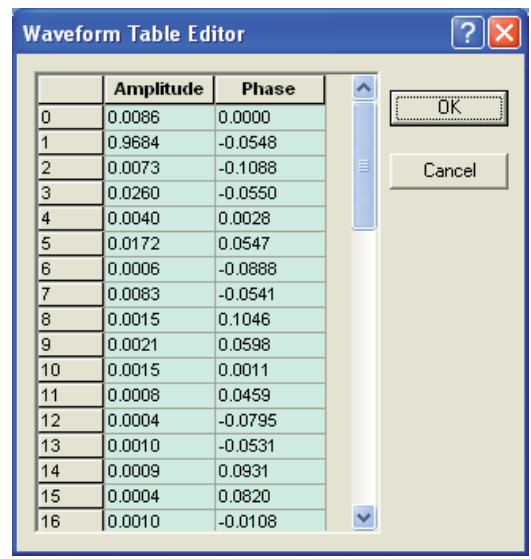

Fig. 5 Table definition 
Fig. 6 and Fig. 7 demonstrates a possible course of voltage in the network, if odd harmonics reached maximum values allowed by the standard ČSN EN 50160 .
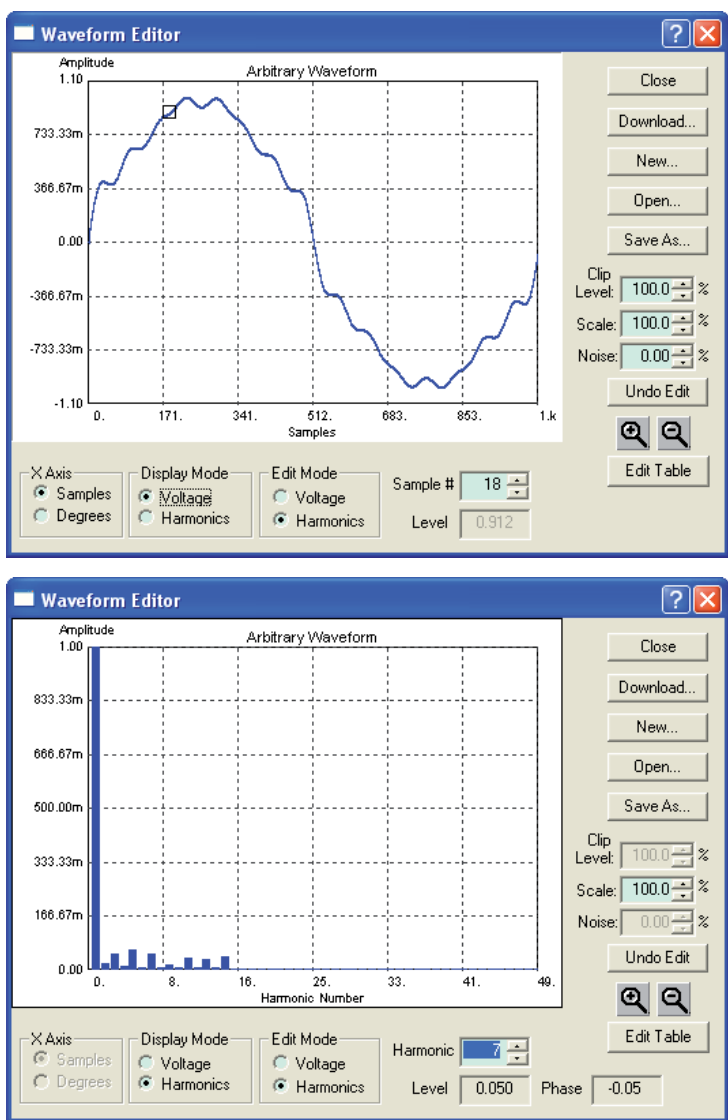

Fig. 6 The limit course of supply voltage according to ČSN EN 50160, harmonics

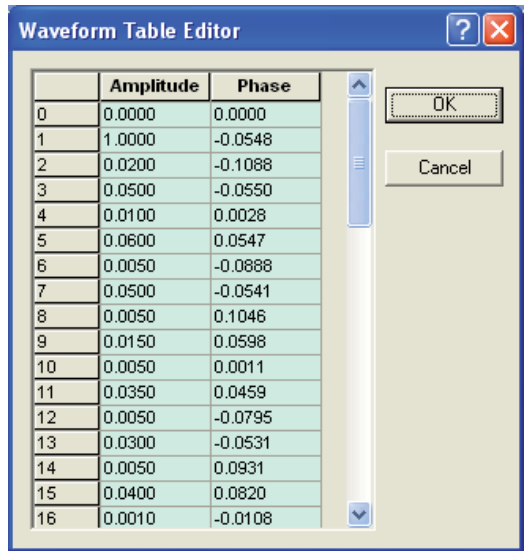

Fig. 7 Table definition (the definition from the $16^{\text {th }}$ hour to the $50^{\text {th }}$ hour are neglected)

On the basis of long-time periodical power quality measurements it is clear that the content of harmonics in the supply network is not significantly increased and in some cases, harmonics may be decreased. The original assumptions that the increase of appliances with switching sources will result in significantly worse electric power quality were not confirmed.

In rare cases, the limit of some harmonics or another quality parameter may be significantly exceeded, but there is not impact on the users. On the other hand, sometimes there is an impact on the users even though the electric power quality limits are not exceeded.

There are continuous changes within the electric distribution network. These changes depend on the number of connected appliances and the amount of connected load. The character of the load as well as its compatibility with the network and other appliances is important as well. It is no longer true that there is voltage of sinusoidal course with the effective value of $230 \mathrm{~V}$ (earlier $220 \mathrm{~V}$ ) in the network. The sinusoidal course of the voltage is more or less deformed depending on the amount of loads of non-linear character. However, the positive aspect is the fact that, in the past years, the network has been stabilized with respect to frequency, which shows almost no deviations. It is so stable that even engine speed does not change, or that pulses for hours can be derived from it. There has also been no previously expected dramatic rise in harmonics and flicker. If such situation had occurred, many supply networks would have to be reconstructed and the output of the sources would have to be increased. However, the costs would have been enormous.

At present, the power supply is very good and stable and in most cases, the qualitative parameters of the supplied electric power are not exceeded. There are obviously certain locations where these parameters cannot be fulfilled. They include places near industrial production or consumption at the end of a supply network branch. In these cases, for example flicker is solved by purchasing very high quality light sources not sensitive to voltage fluctuation from the side of the electric power supplier.

\section{Conclusion}

Since the light source in response to any change in the amplitude of voltage change luminous flux emitted (flicker), as one of the quality parameters according to EN 50160 are transmitted through the light source and the disruptive effects of voltage fluctuations and the living beings (humans). Flashing light sources significantly impairs vision, it causing discomfort and increases fatigue. (Velička, 2008) Flashing light sources may also cause deterioration in the quality of work, in some cases, may cause accidents in the workplace. Another important 
parameter mentioned in the article overvoltage that may directly lead to electric shocks or damage to or destruction of equipment, which subsequently leads to accidents. These injuries can be directly character of electric shock or mechanical nature. In many cases, the overvoltage has also resulted fires all with all known consequences. All these possible effects of power quality parameters led to the clear quantitative limits according to EN 50160.

\section{Acknowledgments}

This article was prepared under the support of the research, development and innovation grant project "Objectification of the electricity production and transmission facilities threats and risks", code number VF20112013019. A specific grant giver is the Ministry of Interior of the Czech Republic within the program of Security research for the needs of the state in the years 2010-2015.

\section{References}

ČSN EN 50160 ed.3.(330122) (2011). Charakteristiky napěti elektrické energie dodávané z veřejných distribučních sití, CENELEC. překlad: Úřad pro technickou normalizaci, metrologii a státní zkušebnictví, 2011, 32 p. (in Czech)

ČSN EN 61000 - 4 - 15 ed. 2 (333432) (2011). Elektromagnetická kompatibilita (EMC) - Část 4 - 15: Měř́č blikáni - Specifikace funkce a dimenzování, CENELEC 1997, převzatá IEC (The International Electrotechnical Commision), překlad: NELKO Tanvald a Úřad pro technickou normalizaci, metrologii a státní zkušebnictví, 2011, 56p. (in Czech)

ČSN EN 61000 - 4 - 30 ed. 2. (333432) (2009). Elektromagnetická kompatibilita (EMC) - Část 4 - 30: Zkušební a měřici technika - Metody měření kvality energie., převzatá EN, překlad úvodní strany: NELKO Tanvald a Úřad pro technickou normalizaci, metrologii a státní zkušebnictví, 2009, 40 p. (in Czech)

EN 50160 (2010). Voltage characteristics of electricity supplied by public electricity networks, 2010.

IEC 61000 - 4 - 15 (2010). Electromagnetic compatibility (EMC) - Part 4-15: Testing and measurement techniques - Flickermeter - Functional and design specifications, 2010.

IEC 61000 - 4 - 30 (2008). Electromagnetic compatibility (EMC) - Part 4-30: Testing and measurement techniques - Power quality measurement methods, 2008.

VELIČKA, R. (2008). Moderní principy testování (vliv transformátoru na prenos kolísání napětí - flickeru), Disertační práce, obor Technická kybernetika, VŠB - TU Ostrava 2008, 91 p. (in Czech) 